\title{
The Concept of the "Zone of High Environmental Hazard" Pursuant to the Contemporary Russian Legislation
}

\author{
Dinara Anvarovna Musabirova ${ }^{1} \&$ Irina Viktorovna Kostyuk ${ }^{1}$ \\ ${ }^{1}$ Kazan Federal University, Naberezhnye Chelny, Russia \\ Correspondence: Musabirova D. A., Syuyumbike Avenue, Building 10A, Naberezhnye Chelny, Republic of \\ Tatarstan, Russian Federation
}

Received: February 28, 2015 Accepted: March 20, 2015 Online Published: April 24, 2015

doi:10.5539/res.v7n6p93 URL: http://dx.doi.org/10.5539/res.v7n6p93

\begin{abstract}
This article introduces and defines the concept and criteria of the "zone of high environmental hazard" towards application of this legal category in legislation and law enforcement. Author reveals the peculiarities of intersectoral legal regulation of the relations when using the objects of high environmental hazard in public circulation, as well as considers the approaches of Russian and foreign law enforcement to protect the interests of citizens and society as a whole against the negative effects of high-risk facilities to the environment. The priority of the public interest with respect to the environmental component of the state's functions and measures to implement the protection of the civil rights and legitimate interests are formalized.
\end{abstract}

Keywords: protection of civil rights; zone of high environmental hazard; favorable environment; source of increased danger; ecology; legal safeguards

\section{Introduction}

The Russian Federation is a state governed by the rule of law. In this regard the Constitution of the Russian Federation proceeds from the fact that a human, his rights and freedoms are the supreme value, whereas the recognition, observance and protection of human and civil rights and freedoms are the main duties of the state.

The basic right of every citizen is entitled to a favorable environment, reliable information about its condition and compensation for damage caused to his health or property by environmental offense; this is provided by legal regulations of Art. 42 of the Russian Federation Constitution. Its realization and protection are particularly relevant when choosing a place of human residence (Sorokin, 2010).

The right of an environment, favorable to human's life, is the first and most important natural human right, which emerged with his appearance in nature. A human naturally needs a favorable environment. In unfavorable environment, for example, in a polluted atmosphere, hydrosphere, lithosphere, etc., he will degrade or even die out.

The right to a healthy environment is one of the basic human rights. The environment is the basis for sustainable development, professional and personal life of the nations, including peoples of the Russian Federation. Though, its history is not rooted in remote ages; this human right refers to the younger generation of rights, which has been stated in the international and national records in the second half of the last century as the third generation of human rights. A feature of such rights is that they are collective in the nature, i.e. represent the rights of certain social communities: peoples, nations, minorities, indigenous peoples, associations, etc.

This right can be considered in both the broad and narrow sense. In the first case the issue is the right to receive trustworthy and not misleading information about the objective status of the certain places in Russia, where natural environment is unfavorable for a human, because of both his own activities (water pollution by oil, etc.) and natural disasters (earthquakes, floods, mudslides, etc.).

At the same time it can be considered as a subjective right of the individuals to know the details about the adverse state of nature in their traditional territories (for example, to be eligible for compensation and benefits to residents of the areas affected by the Chernobyl disaster). In the same sense, the right to receive trustworthy information may belong to persons, whose relatives are living in an adverse environment, as well as citizens, who are sent there to work or on a business trip. 
In the second case, this law is an authority of the corresponding subject to appeal to the bodies of power in order to obtain the necessary information about the environment. But in any case, the embodiment of this right cannot be used in prejudice of others.

It should be noted that the existing legal provisions do not provide at all the adequate conditions for the realization of this right, first and foremost, because the current legislation does not contain a definition of environmental information. This is a negative fact demonstrating the ambiguity of the contemporary conceptual framework of the significant part of the laws that is typical for contemporary development of the state law. A few definitions, existing in this domain, are little functional or abstract, because are intended only for the purposes of a specific legislative act, and also cover just a small part of the environmental information. Meantime, in the context of exercising the civil right to information about the state of the environment and its protection, regulatory solution to this problem is essential.

\section{Methodology}

Environmental protection problem is one of the most relevant issues, because it influences the life on Earth, human health and welfare. This problem was deteriorated in the XX century, when the intense development of industry and transport, as well as, imperfect technology processes, has led to pollution of air, water and soil. In this regard Russia is not an exception (Snezhko, 1999; Matatova, 2012; Zankina, 2005; Kazakov, 2007; Vyphanova, 2009; Vasilchenko, 2008; Brinchuk, 2014; Anisimov, 1997).

One of the areas in international relations is the development of the concept of ecological security based on the principles of international environmental law (Birnie \& Boyle, 2002; Holder \& Lee, 2007). An example of such cooperation is the imposed requirement of the International Olympic Committee to the organizer of the Olympic Games, who is responsible for the construction of Olympic facilities. Discussions about the environmental safety concept are going on even today, as evidenced by the selection of the articles published in the Yearbook of International Environmental Law (Humle, 2009; Wouters et al., 2009; Scholtz, 2009; Voigt, 2009).

In many large cities of almost all countries, the maximum permissible concentrations of harmful substances in the air are exceeded by more than 10 times. The practice of the European Union, which defines the priority areas to combat the negative impact on the environment, is based on the fundamental principle of the environment protection, called "the source principle" (Winter, 2004). Application of harmful substances pollution standards to control air pollution is preferable in comparison with ambient air quality standards. In the field of air protection, the most striking example of the application of concerned principle is the obligation to use the "Best Available Techniques" (BAT), which is regulated by the Directive 96/61/EC of the Council of the European Union of 24.09.1996 entitled "Integrated Pollution Prevention and Control (IPPC)". This principle has been adopted by the Russian environmentalists when establishing standards.

In furtherance of the said provisions of the main act of the state, the Housing Code of the Russian Federation (hereinafter HC RF) stipulates in the Art.2 "Providing conditions to exercise the right to housing" that the state authorities and local self-governing bodies should provide the conditions within their powers for citizens to exercise their right to housing. Special attention is paid to this issue in the Federal Target Program "Housing for 2011-2015".

It should be noted that the implementation and protection of the civil right to housing is still relevant in the process of acquiring the premises, because environmentally safe and clean living environment is an object that can fully protect the human organism against adverse environmental factors. Parameters of the living environment should ensure the preservation of health and human performance during the entire period of his life. National security of Russia is closely interlinked to the environmental aspects of civil life and activity.

The most common threat to people is their habitation or property ownership in sanitary protection zones (hereinafter, SPZ). Analysis of the information received from the 80 territorial administrations of the Federal Service for Supervision of Natural Recourse Usage (Rospotrebnadzor) showed that in the Russian Federation in 2005 , the number of companies and organizations that have established SPZ, though not organized, amounted for 76,968 with the total population of $2,671,421$ people that is about $2 \%$ of the commonwealth.

Unfortunately, more recent data could not be found, though the analysis of the latest judicial practice, at least in Russian, shows that the situation in this area has not undergone any major changes. Moreover, it has become even more frightening, because of the possible accumulation of various hazardous chemical elements in these sites.

As known, human adapts to environmental conditions and his life may be regarded as continuous adaptation to these conditions. Presently, it is ascertained that a significant part of human diseases are associated with 
environmental degradation in the ecosystem. At that, adapting to adverse environmental conditions, the human organism is constantly experiencing stress and physical fatigue.

At the same time, the atmosphere of any living and working environment may include more than 400 compounds, different in chemical nature. Many of these substances do not have set standards of maximum allowable concentrations, thus they are not monitored and their impact on human health is unaccounted (Perikova et al., 2009).

As a rule, environmental hazards are associated with non-standard, extremal emergency situations and accidents, which involve a negative impact. Such a zone, however, is called an "accident zone" or "crisis zone".

Environmental pollution is resulted not only from accidents and environmental disasters, but in most cases, from the everyday activities of the various production facilities (Tranin, 2013). Their damage, as a result of the permanent imperceptible growing impact, can be much more destructive than the obvious man-made disaster or the accident.

The Russian Federation practices a principle of the presumption of ecological danger (Art.3 of the Federal Law "On Environmental Protection"), which lies in the fact that any economic activity and, therefore, any object of such activity is a priory deemed environmentally hazardous. The main objective of such a presumption is to prevent (keep to a minimum) the environmental hazards, posed by economic activity.

Today, the problem of resettlement of the residents, living in the territory of SPZ of operating enterprises, still remains unsolved. According to the provisions of SanPiN 2.2.1/2.1.1.1200-03, possessors of a right of production facilities are responsible to take actions independently on resettlement of people from these SPZs. Occupation of dwelling near industrial enterprises contradicts one of the basic conditions for realization of the constitutional civil right to a healthy environment, and therefore, the fact of living in such area can serve a basis for the judicial recourse to protect the violated right and compensation for harm to the health (Laskin \& Semenchenko, 2012).

\section{Results}

According to the Art.52 "Requirements for environmental protection when establishing protection and security zones" of the Federal Law "On Environmental Protection", to protect the conditions of human life and activities, the habitat of plants, animals and other organisms around the industrial areas and objects of economic and other activities that affect adversely on the environment, protection and security zones are established, including the SPZ, in the neighborhoods, micro-districts of urban and rural areas; these are green belts, forest and parkland zones and other areas with limited regime of ecosystem exploitation.

The implementation of the zoning principle includes empowering certain areas a special legal status, different from that of adjacent areas; establishment of a special or differentiated legal regimes; introduction of additional restrictions and prohibitions; the availability of sanctions for violation of the regime restrictions; granting of special subjects of environmental management with special powers in relation to the other participants of the legal regime; the existence of special procedural rules that establish the order of declaration and (or) allocation of the zones.

The creation of such zones, in particular, is provided by the Town Planning Code of Russia (Art. 35); the Federal Laws "On the Sanitary-Epidemiological Welfare of the Population" (Art. 12), "On Air Protection" (Art. 16), and "On the Use of Atomic Energy" (Art. 31), etc.

Specific requirements for the establishment of the SPZ and their regime is regulated by SanPiN 2.2.1/2.1.1.1031-01 "The design, construction, reconstruction and operation of enterprises, planning and development of residential areas" and "Sanitary protection zones and sanitary classification of enterprises, structures and other facilities", approved by the Chief State Medical Officer of the Russian Federation on May 17, 2001. Thus, in accordance with these regulations, the enterprises, as well as their buildings and structures with technological processes, which are sources of environmental impact on human habitat and health, must be separated from the residential area of the SPZ.

The Code of Inland Water Transport of the Russian Federation uses the concept of "water protection zone", which is the territory adjacent to the shoreline of the seas, rivers, streams, canals, lakes, and reservoirs, and which is subject to a special regime for economic and other activities. Special regime is set in order to prevent pollution, contamination, and siltation of water bodies and their depletion of water, as well as conservation of habitat of aquatic biological resources and other objects of flora and fauna (Part 1, Art. 65).

Forest Code of the Russian Federation also mentions several types of territorial protection in order to meet the 
objectives of creating protected areas (Art. 4 and Art. 12), since the purpose of their creation is much broader than the concept of "forests protection" (Art. 54). These are, for example, "specially protected forest areas", which include also the "preserve forest areas", etc. (Art. 102).

In order to ensure the trouble-free operation of air transport, Art. 46-47 of the Air Code of the Russian Federation sets the following restrictions. Firstly, the design, construction and development of urban and rural settlements, as well as construction and reconstruction of industrial, agricultural and other facilities within the aerodrome environs should be conducted in compliance with the safety requirements of aircraft traffic, taking into account the possible negative effects of aerodrome equipment and aircraft operations on the public health and the activities of legal entities, as well as in agreement with the owner of the airdrome.

Secondly, siting of the buildings, communication lines, power lines, radio and other objects that may threaten the safety of aircraft flights or interfere with radio equipment, installed at the airdrome, to be agreed with the owner of the airdrome and implemented in accordance with the Air Law of the Russian Federation.

Another special category of land is that of pipeline transportation. These are plots of land as part of the subcategory of land transport, which are used or intended to support the activities of organizations and operation of pipeline transport. In order to ensure the activities of organizations and operation of pipeline transport, plots of land may be provided for the following needs: placement of oil, gas and other pipelines; siting of facilities required for operation, maintenance, construction, reconstruction, repair, and development of surface and underground buildings, erections, structures, devices, and other facilities of pipeline transportation; and the establishment of security zones with special conditions of use of land.

The excess of normative standards on emissions of pollutants discharges, or more simply, violations of environmental legislation, directly results in the emergence of adverse changes in the environment, causing the deterioration of public health that is reflected in the legally prescribed opportunity of using appropriate land.

The objective of current study was to determine the peculiarities of statutory regulation of relations to protect both citizens when acquiring premises, as well as the environment in general in the Russian Federation through the rather-legal, empirical, and formal-logical methods of cognition.

At the same time, the study of this subject should not push us to other extremity: automatic recognition of any object and activity as potentially dangerous may simply paralyze normal course of public life. In this regard, it is necessary to find the dividing line that should distinguish the objects and activities, related to the unconditional risk, and thus making living in the affected area impossible, from those, which are fraught with some danger, though their impact is quite acceptable and will not cause substantial harm both to human life and health, as well as the environment.

\section{Discussion}

Thus, we cannot accept all the zones of production activities to be dangerous.

In our view, only those companies that are engaged in activities, where the potential threat turns into a real hazard, should be classified as dangerous. In support of this thesis, we can introduce a rule of jurisprudence that is well known to everyone in Russia: "The attribution of the enterprise, institution or organization to one that represents high environmental hazard shall be independently decided by arbitral tribunal in each particular case". This judicial statement was introduced more than twenty years ago and, nevertheless, does not lose its relevance.

Classification of industrial productions and other objects to ecologically dangerous enterprises is confirmed by the presence of two criteria.

The first criterion is valid harm (i.e., damage, which is subject to the environmental and hygienic standards, approved by legislation) to the environment, person, or property caused by the operation of high consequence facility, as well as a high risk of significant harm as a result of an accident at a high consequence facility, excess emissions (discharges), which may be manifested in the destruction, deterioration or damage to the environmental components, high and extremely high environmental pollution, deterioration of human health, up to deaths, and damage or destruction of property.

The second criterion is consolidation into law the increased requirements for environmental protection and ecological safety in the course of operation (construction, design, location, conservation, or liquidation) of ecologically high consequence facility (Tranin, 2013).

Thus, a source of increased environmental hazard refers to hazardous production facilities, carrying out legitimate activities, usually insured and related to ownership and use of harmful objects, whose quantitative parameter excludes the possibility of a complete human control at appropriate levels that thereby creates 
potentially increased danger to the environmental components, human life and health.

Practice shows that exactly the SPZ have all the features of the zones with high environmental hazards. They are an indispensable element of any object, and the source of the impact on the environment and human health. Use of the SPZ sites is subject to restrictions set by the current legislation.

The territory of the SPZ is designed to: ensure the reduction of the exposure level to the required hygienic standards in all impact factors beyond its borders; create a sanitary barrier between the territory of the enterprise (group of enterprises) and residential areas; organization of additional green areas, providing screening, assimilation and filtration of air pollutants and improving the environmental comfort (Bogolyubov \& Khludeneva, 2009).

Obligations of the enterprise for arrangement of SPZ are not limited to just project development for its recognition and organization, coordination and approval of its spatial quantity. It is also necessary to perform certain actions on execution and registration of corresponding land plot. According to the item 3 of the Art.87 of the Land Code of the Russian Federation, the land plots for industrial and other special-purposes may include for security reasons, protective zones, SPZ and other areas with special conditions of use.

For official registration of restrictions (encumbrances), it is necessary to recognize the SPZ boundaries on the ground, approved by Rospotrebnadzor that is carried out by frontier surveying. Then, based on the generated landmark plan maps, public authorities or local government bodies, depending on who is or was the owner of the land before it was handed over to private ownership, establish the restrictive acts. If protective zone or SPZ is established simultaneously with the provision of land ownership, permanent (unlimited) use or lease, the decisions on establishing the SPZ and providing land may be the content of a single act (for example, regulation of the municipal administration).

The next step is cadastral registration of restrictions (encumbrances) of rights on the land within the boundaries of the SPZ and implementation of their state registration in the manner, prescribed by the Federal Law "On State Registration of Rights to Immovable Property and Transactions therewith".

Introduction of SPZ with respect to a particular site imposes certain kind of constraints, i.e. a special regime is introduced to restrict or prohibit some activities.

Another example of zone with high environmental hazard is a surveillance zone, which is created around nuclear power facilities. In accordance with the Art.1 of the Federal Law "On Radiation Safety", the surveillance zone is understood a territory outside the SPZ, which is subjected to the radiation monitoring. The need to establish such a zone, its size and borders are defined in the project documentation on the basis of the safety performance of nuclear facilities, and are agreed with the Rospotrebnadzor agencies. These include also municipal and industrial waste recovery and recycling areas.

It turns out that allocation of the land spots for construction within these territories seems to be prohibited. Nevertheless, the housing, as well as the sites within these areas still remains extensively involved in the civil circulation.

Purchasing of private premises, as well as the allocation of lands, renewal of their lease, permit for construction of facilities in cities and other settlements not always comply with the requirements of the current urban, land, environmental and administrative (municipal) laws (Vorobieva, 2014).

What are the causes of violations in such cases?

First of all, when issuing building permit, the local administration does not always require all the necessary documents, stipulated by the item 7, Art.51 of the RF Town Planning Code. Thus, in this case, the documents attached to the application, must include a favorable conclusion on examination of project documentation of capital construction object. In particular, this is relevant with respect to the operation of the equipment at base stations of cellular telephone service. However, the availability of such a conclusion results to almost automatic decision, adopted by a judge, concerning the safety of the operation of such facilities.

Secondly, when preparing the necessary documents (site design, etc.), issuing decree to grant (allocate) land plot, concluding lease agreement and issuing building license, local administrations in violation of the law do not carry out adequate verification of documents on territory planning and do not inform the community about the change in the territory planning and proposed future construction.

\section{Conclusion}

Based on the analysis of normative legal acts of the Russian Federation and the general approaches to the concerned problematics in international law, it can be concluded that the zone of high environmental hazard is a 
special land spot, separated in the prescribed manner, which is affected by the legitimate activities of a hazardous industrial or other facilities, associated with the use of deleterious things, whose quantitative parameter at appropriate levels excludes the possibility of a comprehensive human monitoring, potentially creating thereby increased danger to the environmental components, human life and health. The use of this concept and its legal consolidation, in our opinion, would allow one to clearly define in practice the areas, where human habitation and even stay is dangerous to health.

In addition to the state security measures to protect the environment, as well as to guarantee human and civil rights, we should emphasize the role of the civil society in the environmental sphere. The concept of public participation in solving problems related to the environment, which has gained in recent decades a strong position among the dominant political and legal trends, has become an important element of many regulatory systems in the field of worldwide environmental protection.

The availability of the effective mechanism of legal regulation together with the developed self-awareness and social activity are able to resolve legal problems and implement the idea of Art.42 of the Russian Constitution, which establishes the civil right to a favorable environment, reliable information about its condition and compensation for damage caused to his health or property.

The issues concerning self-regulation in considered sphere of civil relations by public organizations, as well as forms and methods of legal means of influencing the manufacturing sector, the public administration system, and the formation of legal awareness of the society, should be investigated in a separate study, which will result in the next article.

\section{Acknowledgement}

In conclusion, author would like to express his gratitude to Kazan Federal University for help rendered when working on the text of the current article. The authors have made equal contributions to this article.

\section{References}

Anisimov, A. (1997). Human and civil rights to a healthy environment: Constitutional and legal aspects. Volgograd.

Birnie, P., \& Boyle, A. (2002). International law: The environment. Oxford University Press.

Bogolyubov, S., \& Khludeneva, N. (2009). Comments to the Federal Law of January 10, 2002, \#7-FZ "On Environmental Protection". Moscow: Yustitsinform.

Brinchuk, M. (2014). The right to a favorable environment as a factor of national security. Astrakhan Bulletin on Environmental Education, 1, 4-116.

Holder, J., \& Lee, M. (2007). Environmental protection, law and policy: Text and materials. Oxford. http://dx.doi.org/10.1017/CBO9780511805981

Humle, K. (2009). Environmental security: Implications for international law. Yaerbook of International Environmental Law.

Kozakov, V. (2007). The human right as an object of protection in a constitutional state. History of State and Law, $14,18-25$.

Laskina, N., \& Semenchenko, E. (2012). Commentary to the Federal Law of July 21, 1997, \#117-FZ “On Safety of Hydraulic Structures". Retrieved December 5, 2014, from http://base.consultant.ru/cons/cgi/online.cgi?req=doc;base=CMB; $=16995 ; \mathrm{div}=\mathrm{LAW} ; \mathrm{mb}=\mathrm{LAW} ; \mathrm{opt}=1$;ts= D2876F87CCB725A3FBF6D23FB4F5D853;rnd=0.5849877913322962

Matatova, M. (2012). Constitutional and legal mechanism for protecting human rights in Russia: Some domestic and international aspects. Constitutional and Municipal Law, 5, 45-49.

Perikova, E., Karataev, O., Taneyeva, A., \& Novikov, V. (2007). Evaluation of wastewater pollution from industrial site of Kazan house-building plant. Proceedings of the higher educational institutions. Energy problems, 11, 145-152.

Scholtz, W. (2009). Collective (environmental) security. The Yeast for the Refinement of International Law.

Snezhko, O. (1999). The constitutional foundations of the state protection of the human and civil rights and freedoms in the Russian Federation. Saratov.

Sorokina, T. (2010). Protection mechanisms of the right to favourable environment. Moscow.

Tranin, A. (2013). Modernization of dangerous industrial enterprises as a factor of providing environmental 
safety: Legal aspects. Environmental Law, 1, 9-17.

Vasilchenko, O. (2008). Development of the constitutional mechanism for protecting human rights and freedoms in Russia. History of State and Law, 22, 4-7.

Voigt, C. (2009). Sustainable security. The Yeast for the Refinement of International Law. http://dx.doi.org/10.1093/yiel/19.1.163

Vorobieva, L. (2014). The Constitution of the Russian Federation and some problems on protection of property and environmental rights of citizens. Problems of Contemporary Science and Practice. The Taurida National University named after Vernadsky, 49, 27-32.

Vyphanova, G. (2009). Legal problems on information support of natural resources and environmental protection. Moscow.

Winter, G. (2004). The legal nature of environmental principles in international, EC and German law. Principles of European Environmental Law. Groningen: Europa Law Publishing.

Wouters, P., Vinogradov, S., \& Magsig, B. (2009). Water security, hydrosolidarity and international law: A river runs through it. The Yeast for the Refinement of International Law. http://dx.doi.org/10.1093/yiel/19.1.97

Zankina, Y. (2005). The concept and essence of human rights. Legal Practice, 1, 23-28.

\section{Copyrights}

Copyright for this article is retained by the author(s), with first publication rights granted to the journal.

This is an open-access article distributed under the terms and conditions of the Creative Commons Attribution license (http://creativecommons.org/licenses/by/3.0/). 